Sir,

\section{Management of ankyloblepharon filiforme adnatum}

Ankyloblepharon filiforme adnatum (AFA) is a rare congenital malformation affecting the eyelids. We report a case describing its management.

\section{Case report}

A male neonate was referred for assessment of his left eyelids. He was born at term, to a primigravid mother, weighing $3150 \mathrm{~g}$. Pregnancy and delivery were unremarkable. There was no family history of ophthalmic or systemic disease. A detailed systemic assessment by a paediatrician was clear.

Ocular examination showed partial fusion of his left upper and lower eyelids by a central, narrow band of tissue, arising from the grey lines (Figure 1). Full eyelid opening was impaired and interpalpebral aperture was limited to $3.5 \mathrm{~mm}$. Right eye examination was normal. The band of tissue was retracted anteriorly with a squint hook, clamped for $10 \mathrm{~s}$, and excised with Vannas scissors at the level of each eyelid margin. The procedure was performed under corneal anaesthesia using benoxinate $0.4 \%$. There was no sign of distress and no bleeding. Subsequent left eye examination did not reveal any other pathology. At 2 years' follow up, logMAR visual acuity was +0.1 in both eyes and examination was normal.

\section{Discussion}

AFA describes single or multiple bands of tissue joining the upper and lower eyelids either unilaterally or bilaterally. It may present as an isolated congenital defect such as in our patient. However, it is always important to actively look for coexisting pathology.

The ophthalmic association of AFA is iridogoniodysgenesis with juvenile glaucoma. ${ }^{1}$ Systemically, AFA is associated with cleft lip and palate, ${ }^{2}$

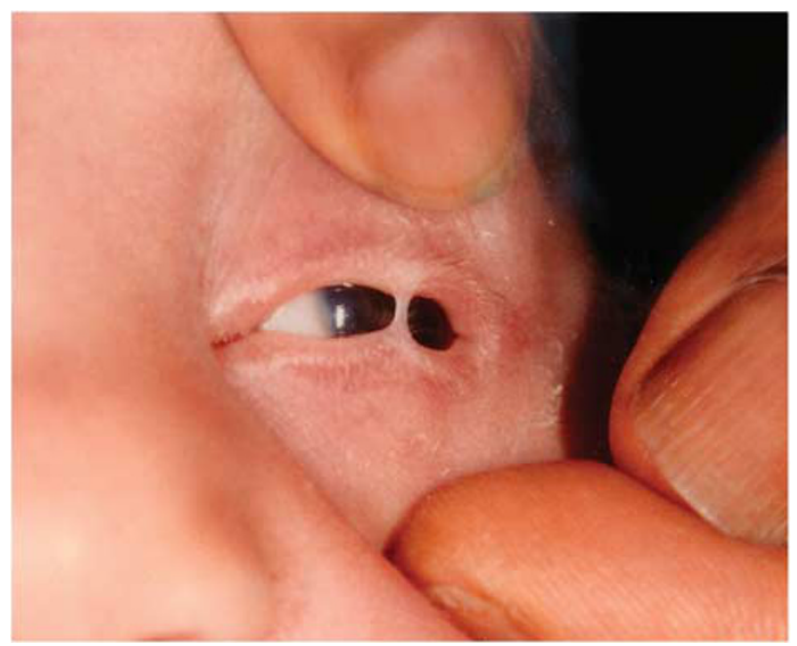

Figure 1 Photograph of the neonate with ankyloblepharon filiforme adnatum showing partial fusion of the left upper and lower eyelids by a band of tissue. occasionally in the context of ectodermal dysplasia syndromes ${ }^{3}$ and popliteal pterygium syndrome. ${ }^{4}$ AFA has also been reported in association with Edward's syndrome, ${ }^{5}$ and $\mathrm{CHANDS}^{6}$ (curly hair, ankyloblepharon, nail dysplasia). Other associations include hydrocephalus, meningomyelocoele, and imperforate anus, ${ }^{7}$ cardiac defects and syndactyly. ${ }^{4}$ Detailed systemic assessment by an experienced paediatrician is therefore imperative in the management of AFA.

Our report illustrates a simple surgical approach that is modified from previously published cases. ${ }^{1,2,4}$ It is safe and well tolerated with the aid of topical anaesthesia. Surgical correction should be performed promptly to minimise any risk of occlusion amblyopia, and enable full examination of the eye.

\section{Conflict of interest}

The authors declare no conflict of interest.

\section{References}

1 Scott MH, Richard JM, Farris BK. Ankyloblepharon filiforme adnatum associated with infantile glaucoma and iridogoniodysgenesis. J Pediatr Ophthalmol Strabismus 1994; 31: 93-95.

2 Long JC, Blandford SE. Ankyloblepharon filiforme adnatum with cleft lip and palate. Am J Ophthalmol 1962; 53 126-129.

3 Vanderhooft SL, Stephan MJ, Sybert VP. Severe skin erosions and scalp infections in AEC syndrome. Pediatr Dermatol 1993; 10: 334-340.

4 Akkermans $\mathrm{CH}$, Stern LM. Ankyloblepharon filiforme adnatum. Br J Ophthalmol 1979; 63: 129-131.

5 Bacal DA, Nelson LB, Zackai EH, Lavrich JB, Kousseff BG, McDonald-McGinn D. Ankyloblepharon filiforme adnatum in trisomy 18. J Pediatr Ophthalmol Strabismus 1993; 30: 337-339.

6 Toriello HV, Lindstrom JA, Waterman DF, Baughman FA. Re-evaluation of CHANDS. I Med Genet 1979; 16: 316-317.

7 Kazarian EL, Goldstein P. Ankyloblepharon filiforme adnatum with hydrocephalus, meningomyelocele, and imperforate anus. Am J Ophthalmol 1977; 84: 355-357.

\section{A loannides ${ }^{1}$ and ND Georgakarakos ${ }^{2}$}

${ }^{1}$ Department of Ophthalmology, Mid-Yorkshire Hospitals NHS Trust, Yorkshire, UK

${ }^{2}$ Institute of Ophthalmology, University College

London, London, UK.

E-mail: antonis@antonis.org

Eye (2011) 25, 823; doi:10.1038/eye.2011.26; published online 25 February 2011

Sir,

Enhanced rod-cone interaction with progressive macular dysfunction

Case report

A 22-year-old man was referred with decreased visual acuity of 4 years duration and bilateral 'positive' 